\title{
MYSM1 wt Allele
}

National Cancer Institute

\section{Source}

National Cancer Institute. MYSM1 wt Allele. NCI Thesaurus. Code C113234.

Human MYSM1 wild-type allele is located in the vicinity of 1 p32.1 and is approximately 45 $\mathrm{kb}$ in length. This allele, which encodes histone H2A deubiquitinase MYSM1 protein, plays a role in histone $2 \mathrm{~A}$ deubiquitination and chromatin remodeling. 